\title{
Microfinance Beyond the Standard? Evaluating Adequacy and Performance of Agricultural Microcredit
}

\author{
Ron Weber $^{* *}$
}

\begin{abstract}
Microfinance was successful in increasing access to credit for micro, small and medium enterprises in developing countries, particularly in urban areas. The offer of installment loans as the standard credit product for new and very small customers has been indentified as one of the keys that enabled microfinance institutions to reach out to formerly unbanked entrepreneurs. However, these standard loans always were considered as inadequate for agricultural entrepreneurs with seasonal production cycles. For this reason, this paper investigates the effects of providing flexible agricultural microfinance loans (flex loans) to farmers as an alternative to standard installment loans. The study was carried out in cooperation with two banks of the AccessHolding Microfinance AG in Tanzania and Madagascar. A mixed-methods approach was applied relying on observations during field visits and in-depth portfolio analyses.

Our results reveal that the combination of standard and flex loans enables the investigated microfinance institution to address a wide range of agricultural producers. Based on our results it seems very unlikely that seasonal agricultural producers would have had credit access without flex loans. Standard loans are only adequate to address non-seasonal agricultural producers. We also find that nonseasonal agricultural producers repay their loans with delinquency rates similar or even better than those of non-farmers. For seasonal agricultural producers a redis-
\end{abstract}

\footnotetext{
* The views expressed in this paper are entirely those of the author and do not necessarily represent those of KfW. The authors are grateful to Access Microfinance Holding AG and LFS Financial Systems GmbH in Berlin, Germany, for the provision of data, in particular Stephan Hödtke and his colleagues from the LFS IT department. Furthermore, we would like to thank all colleagues from AccèsBanque Madagascar for their great support during the field visits in Madagascar and for contributing their expertise; Claudia Schmerler is also acknowledged for her helpful comments.

** $\quad$ Project Manager, KfW.
} 
tribution of principal payments from periods with low agricultural returns (grace periods) to periods when agricultural returns are high is necessary to keep their delinquency rates at the level of non-farmers. Furthermore, we find that flex loans can be offered sustainably and that agricultural lending has become a strategic focus of the Access Bank in Madagascar.

\section{Introduction}

The impacts of microfinance on developing countries are currently discussed controversially. Microfinance has achieved the financial inclusion of millions of micro, small, and medium entrepreneurs that had no access to financial services before (Love and Peria, 2012). Merely thirty years have passed since the foundation of the Grameen Bank, and already there are signs of microcredit oversupply and even borrower over-indebtedness, particularly in emerging countries (Taylor, 2011; Vogelgesang, 2003). However, the contribution of microfinance to investment stimulation, employment generation, and economic development is less controversial (Duvendack et al., 2011; Pande et al., 2012).

Lending techniques applied by microfinance institutions (MFIs) are adequate to reflect the business conditions of many micro, small, and medium enterprises (MSMEs). Loan sizes are adapted to the borrowers' incomes based on intensive client assessments, relationships are established by carefully increasing loan amounts for good borrowers, and loan products are standardized by offering mainly installment loans (standard loans) with loan repayment starting immediately after loan disbursement. Product standardization is even considered as one of the main reasons for the high repayment rates and, hence, the success of microfinance (Armendáriz de Aghion and Morduch, 2000; Jain and Mansuri, 2003). However, product standardization also has several drawbacks.

When repayment schedules cannot be harmonized with investment returns, the number of potential projects that can be realized is limited. For a project to be financed with a short-term installment loan, fast turnovers and regular cash flows of nearly the same level are required. Longer-term projects need time to mature though before they generate returns sufficiently high to repay the loan balance. In consequence, profitable investments might not even be realized due to mismatches between cash flow and repayment obligations (Field et al., 2011). Most MFI clients are, hence, traders, using their loans to finance working capital, and the share of loans for long-term projects remains low (Dalla Pellegrina, 2011).

Moreover, while microfinance has reached many urban entrepreneurs, it still needs to accomplish its mission for MSMEs in rural areas, particularly for entrepreneurs in the agricultural sector (Hermes et al., 2011; Llanto, 2007). Most agricultural production types are characterized by a high level of seasonality leading to mismatches between expenditures during planting season and revenues at the time of harvest (Binswanger and Rosenzweig, 1986). Particularly here, standard loans, which cannot account for seasonal cash-flow patterns of agricultural producers, seem to fall behind. 
The provisioning of microfinance loans with flexible repayment schedules (flex loans) is, hence, stipulated by the literature (e.g., Llanto, 2007; Meyer, 2002; Dalla Pellegrina, 2011; Field et al., 2011). Yet, despite the potential of flex loans to increase the outreach of MFIs, at present only few MFIs are willing to make repayment schedules more flexible.

Based on field visits and data of the management information systems of two banks of the AccessHolding Microfinance AG in Tanzania and Madagascar, this paper provides a mixed-methods evaluation of product adequacy and the effects of providing standard and flex loans to agricultural firms. The rest of this report is organized as follows: In the second part, we will provide a brief discussion why standard loans are mainly applied in microfinance and how this determines the type of MSMEs financed by MFIs. In the third part, the analyzed MFIs will be briefly presented. Based on this background, we will present four evaluation questions and the evaluation methodology. In the fourth part, we will assess agricultural lending in both banks along these evaluation questions.

\section{Lending Principles in Microfinance}

Driven by negative experiences of the supply-led development finance period in the 1960s and 1970s and the failure of state-owned development banks in the 1980s (Adams and Graham, 1981; Maurer, 2011), governments and central banks in many developing countries have started to improve the regulatory and operating environment in the financial sector. These improvements were important preconditions for the successful development of the commercial microfinance industry, which is driven by various attempts such as developing regular banks to better serve MSMEs and professionalizing existing and creating new MFIs (Krahnen and Schmidt, 1994; Maurer, 2011). For MFIs, informal MSMEs have represented the typical target clients as informal MSMEs are normally neglected by regular banks. Rather than applying the conventional, collateral-based lending approach followed by regular banks or the joint liability principle of group lending mostly applied by non-commercial MFIs, commercial MFIs typically use income based individual (liability) lending techniques instead. Thereby the family and the business income, i.e., the total household income, determines the repayment capacity of a loan applicant and is the basis for the decision of the MFI whether a loan is granted and how much credit will be disbursed. As reliable income statements or balance sheet data are hardly available in the informal MSME sector, MFIs themselves carry out detailed assessments of loan applicants to evaluate their repayment capacities ${ }^{1}$. Driven by the support of donors, development finance institutions, and commercial banks, individual lending MFIs can today be found all over the world, although mainly in urban areas (Llanto, 2007).

For further information on the principles of microfinance the reader is referred to Armendáriz de Aghion and Morduch (2010) and Kong and Turvey (2008). 
One of the main reasons for the success of MFIs is the provisioning of standard loans. Standard loans are also widely applied by individual lending MFIs. Despite the fact that installments of standard loans are adapted to the income of the borrower, including the cash flow of the financed project and other income sources of the borrower's household (Armendáriz de Aghion and Morduch, 2010), repayment schedules of standard loans cannot be harmonized with the cash-flow occurrence of the borrower. Thus, standard loans might be adequate for businesses generating fast returns on a regular basis, e.g., petty traders (Llanto, 2007). However, for longer-term projects with irregular and uncertain return patterns, standard loans seem counterintuitive as such projects need time to mature before first returns are realized. The project can only be financed if an entrepreneur is able to smooth temporary cash-flow shortfalls of the financed project by other income sources. In consequence, profitable projects cannot be realized at all or only with higher repayment risks when cash flow and repayment obligations do not match (Field et al., 2011). Hence, product standardization might reduce default risks for clients with continuous cash flows but limits the focus of MFIs to projects fulfilling the product requirements (Weber and Musshoff, 2012). Unsurprisingly, most MFI clients are traders with fast turnovers, using their loans to finance mainly working capital. The share of long-term loans offered by MFIs and especially loans to entrepreneurs with seasonal returns typically found in the agricultural sector, however, remains low (Dalla Pellegrina, 2011).

Agricultural production is often characterized by a high level of seasonality which frequently leads to periodical imbalances between expenditures in the planting and revenues in the harvesting seasons (Binswanger and Rosenzweig, 1986). For this reason, loans with flexible loan repayment schedules harmonized with agricultural production cycles are often stipulated in the agricultural economics literature (Meyer, 2002; Dalla Pellegrina, 2011). In this context, Meyer (2002) argues that firms in Bangladesh with significant agricultural income would be better served with loan repayment schedules matching expected cash flows and shifting principal repayment to the time of harvest. Furthermore, Dalla Pellegrina (2011) states that compared to (flexible) loans of informal money lenders and conventional banks, standard loans of MFIs are less suitable to finance agricultural projects. The absence of adequate loan products for agricultural firms is, hence, considered to be one reason why the penetration of agricultural clients by MFIs is still low (Christen and Pearce, 2005; Llanto, 2007).

In addition to inadequate loan products, the outreach of MFIs to rural areas where most of the agricultural production takes place is constrained by higher operational costs when compared to urban areas. The reason is that distances are longer and population densities are lower, making it more time and fuel consuming for banks to approach and to monitor borrowers (Armendáriz de Aghion and Morduch, 2010; Caudill et al., 2009). Collection costs are considered to be one of the largest operational cost components in microfinance (Shankar, 2007). Here, grace periods increase the time period that loan amounts are outstanding and, hence, lead to higher interest returns for the MFI, contributing to compensate for higher operational costs. 
Despite the potential of flexible repayment schedules to increase the outreach of MFIs to rural areas, most MFIs are still reluctant to make repayment schedules more flexible. They might fear that more flexibility reduces repayment rates. However, there is no empirical evidence that could support this concern. However, most research focusing on the effects of flexible repayment schedules on loan repayment is based on experiments, with mixed results that need to be proven in reality yet. In a field experiment in India, Field and Pande (2008) randomly assigned microfinance loans to borrowing groups of a MFI with either monthly or weekly repayment installments. They find that different repayment schedules have no significant influence on loan delinquencies. In a later experiment with the same MFI, Field et al. (2011) complement their first investigations by analyzing the effect of a two-month grace period ${ }^{2}$ on loan delinquencies of borrowers. They find higher loan delinquencies for loans with grace periods. However, despite their randomization, the granting of grace periods was arbitrary and did not depend on the underlying cash-flow patterns of the borrowers. Hence, they were not able to control whether the investigated borrowers needed the grace period to compensate cashflow induced liquidity shortfalls. In a similar experiment with randomly assigned loans to borrowing groups in India, Czura et al. (2011) tried to extend the earlier research and implicitly addressed potential cash-flow shortfalls of the borrowers. To limit other sources of influence, they only focused on dairy farmers. All borrowers in their experiment used the loans to buy lactating dairy cows, i.e., cows that were giving milk at the time of purchase but that would stop giving milk for two months after the lactation phase. This event was expected to occur a certain time after loan disbursement, and, hence, the borrower would suffer a cash-flow shortfall at that moment. Czura et al. (2011) assigned different loan types to the borrowers: standard loans, loans with pre-defined grace periods, and loans with flexible grace periods where the borrower was allowed to postpone up to two repayment installments at any time three months after loan disbursement ${ }^{3}$. Their results show that loan delinquencies of loans with flexible grace periods were not higher than those of standard loans. Their experimental results showing that grace periods do not undermine repayment discipline are further supported by Godquin (2004), who investigates the loan repayment behavior of MFI borrowers in Bangladesh. She finds that loans with grace periods have significantly lower loan delinquencies than standard loans. These findings suggest that switching from standard loans to flex loans does not necessarily affect repayment quality. Moreover, these findings support the argument that decreasing the number of repay-

2 During a grace period the borrower only needs to partly fulfill his repayment obligations (principal, interests). The graced repayment obligations are postponed to the future, usually when returns occur.

3 Given the monthly repayment plans, the postponement of two installments is similar to a two-month grace period. Two months is the average resting phase of a dairy cow between two lactation periods. During the resting phase the cow produces no milk, and, hence, generates only costs and no returns. 
ment installments bears potential to increase efficiency of MFIs as flex loans are not associated with higher loan defaults.

Hence, it is not surprising that a recent approach to enhance access to finance for agricultural MSMEs is driven by the commercial microfinance industry. Christen and Pearce (2005) have presented the principles of this new "Agricultural Microfinance Model" which adapts the general microfinance approach for agricultural MSMEs. In this attempt, the German AccessHolding Microfinance AG (represented through Access Banks in currently seven developing and emerging countries) was among the first institutions that introduced flex loans for agricultural MSMEs in Africa and in Madagascar in particular.

\section{Institutions}

The institutions investigated in our evaluation are AccessBank Tanzania (ABT) and AccèsBanque Madagascar (ABM). Currently only ABM has introduced and offers flex loans.

ABT is a commercial MFI with a special focus on MSMEs. The bank operates in Tanzania as a fully-fledged commercial bank and is owned by the five founders, the AccessHolding Microfinance AG, the Belgian Investment Company for Developing Countries, KfW (the German Development Bank), the International Finance Corporation (IFC), and the African Development Bank. During the first four years of operation from 2007 to 2011, the bank grew steadily and currently operates eight branch offices in the greater Dar es Salaam area. ABT disburses all loans in the local currency, Tanzania Shilling (TZS), and procedures of the bank are specially designed for and only allow for disbursing individual loans. Up to date (2013), the bank only offers standard loans in the micro segment, and loans to agricultural entrepreneurs are still granted under the standard loan procedures. Hence, they are not yet adapted to the agricultural production cycles and have fixed repayment schedules and maturities without grace periods.

ABM operates as a fully-fledged commercial MSME bank in Madagascar and is owned by its founders, the AccessHolding Microfinance AG, BFV-Société Générale, KfW, IFC, and the Triodos-Doen Fund. ABM offers its services through 17 branch offices. In contrast to ABT, the branch network of ABM reaches far beyond the capital Antananarivo where ABM began its business after foundation in 2007. Like ABT, ABM also disburses all loans only in local currency (MadagascarAriary, MGA) and only on an individual lending basis. At the moment, there are six different business loan products in the micro segment: standard loans, housing loans, emergency loans for unforeseen private expenditures (e.g., accidents), flex loans, warehouse receipt loans ${ }^{4}$, and value chain loans in cooperation with an input

4 ABM owns the warehouses and takes stocks of crops (currently only rice) from farmers (at market prices) as loan collateral. During the loan repayment period, the stock can be reduced according to the changing collateral requirements. ABM charges the client with a stock depositing fee. Besides getting the stock as collateral accepted, the farmer benefits from increasing crop prices after the harvesting season. 
supplier ${ }^{5}$. Besides loans, both banks offer various types of deposits, ATM services (only ABT), and money transfer services (Western Union, Money Gram).

The loan granting process of both banks is typical for commercial MFIs involved in individual lending and is similar to other banks of the AccessHolding

Table 1. Client Characteristics of AccessBank Tanzania and AccèsBanque Madagascar

\begin{tabular}{|c|c|c|c|c|c|c|c|c|c|c|c|}
\hline \multirow[b]{3}{*}{ Variable } & \multirow[b]{3}{*}{ Unit } & \multicolumn{4}{|c|}{ AccessBank Tanzania } & \multicolumn{6}{|c|}{ AccèsBanque Madagascar } \\
\hline & & \multicolumn{2}{|c|}{$\begin{array}{c}\text { Farmer }^{1} \\
\text { Standard Loan }\end{array}$} & \multicolumn{2}{|c|}{ Non-Farmer } & \multicolumn{2}{|c|}{$\begin{array}{c}\text { Farmer }^{3} \\
\text { Standard Loan }\end{array}$} & \multicolumn{2}{|c|}{$\begin{array}{l}\text { Farmer }^{3} \\
\text { Flex Loan }\end{array}$} & \multicolumn{2}{|c|}{ Non-Farmer } \\
\hline & & Mean & $\mathrm{SD}^{2}$ & Mean & $\mathrm{SD}^{2}$ & Mean & $\mathrm{SD}^{2}$ & Mean & $\mathrm{SD}^{2}$ & Mean & $\mathrm{SD}^{2}$ \\
\hline Household Income & $\mathrm{CU}^{3}$ & 986 & 1,084 & 1,040 & 1,232 & $1,944^{* * *}$ & 2,714 & $575^{\star \star *}$ & 853 & 3,620 & 6,755 \\
\hline Household Expenses & $\mathrm{CU}^{3}$ & - & - & - & - & $1,632^{\star * \star}$ & 1,511 & $357^{* \star \star}$ & 694 & 3,264 & 6,480 \\
\hline Age & years & $44^{* * *}$ & 9.42 & 39 & 8.32 & $40.61^{\star * \star}$ & 10.26 & $41.67^{* \star *}$ & 11.07 & 39.80 & 9.74 \\
\hline Gender (female) & $\%$ & $71^{* * *}$ & - & 40 & - & $51^{* \star *}$ & - & $26^{* * *}$ & - & 59 & - \\
\hline Family Members & number & $5.29^{* * *}$ & 2.08 & 5.00 & 2.00 & $4.76^{\star \star \star}$ & 1.89 & $5.55^{\star \star *}$ & 2.15 & 4.66 & 1.86 \\
\hline $\begin{array}{l}\text { Marital Status } \\
\text { (married) }\end{array}$ & number & - & - & - & - & $88^{\star * *}$ & - & $89^{* \star *}$ & - & 85 & - \\
\hline Higher Education & $\%$ & $30^{* * *}$ & - & 24 & - & - & - & - & - & - & - \\
\hline Work Experience & month & - & - & - & - & $86.62^{* \star *}$ & 65.70 & $165^{\star * *}$ & 115 & 107.47 & 74.31 \\
\hline Repeat Client & $\%$ & 39 & - & 37 & - & $35^{\star \star \star}$ & - & $11^{* * *}$ & - & 37 & - \\
\hline Deposit & $\%$ & 72 & - & 47 & - & $68^{* \star *}$ & - & $71^{* * *}$ & - & 66 & - \\
\hline $\begin{array}{l}\text { Number of Observations } \\
\text { (total) }\end{array}$ & number & \multicolumn{2}{|c|}{538} & \multicolumn{2}{|c|}{20,796} & \multicolumn{2}{|c|}{3,113} & \multicolumn{2}{|c|}{2,221} & \multicolumn{2}{|c|}{88,782} \\
\hline Animal Producers & number & \multicolumn{2}{|c|}{531} & \multicolumn{2}{|c|}{ - } & \multicolumn{2}{|c|}{3,083} & \multicolumn{2}{|c|}{222} & \multicolumn{2}{|c|}{ - } \\
\hline $\begin{array}{l}\text { Crop and Vegetable } \\
\text { Producers }\end{array}$ & number & \multicolumn{2}{|c|}{7} & \multicolumn{2}{|c|}{ - } & \multicolumn{2}{|c|}{30} & \multicolumn{2}{|c|}{1,999} & \multicolumn{2}{|c|}{ - } \\
\hline
\end{tabular}

1 Farmer Standard Loan, agricultural firms with standard loan; Farmer Flex Loan, agricultural firm with flex loan; Non-Farmer, non-farmer with standard or flex loan; ***,**,* indicate a significant mean difference between farmers with standard loans and farmers with flex loans compared to non-farmers on a $1 \%, 5 \%$ and $10 \%$ level, respectively. Comprises only primary agricultural producers, i.e., livestock, crop as well as fruit and vegetable producers.

2 SD, Standard Deviation.

3 CU, Currency Unit in thousand Tanzania Shilling for AccessBank Tanzania and in thousand Malagasy-Ariary for AccèsBanque Madagascar.

5 ABM cooperates with an input supplier for poultry production. If a loan applicant fulfills the requirements to raise a high-yield poultry breed, he will use the loan from ABM to buy a full package to raise these chickens from the input supplier (chicken, vaccination, feed). Thus, the farmer generates higher returns through a better chicken breed, and the bank reduces its risk that the client's business will work out unsuccessfully. 
Microfinance AG (Weber and Musshoff, 2013). In addition to intensive on-site client assessments, this includes the verification of investigated information through cross-checks carried out by the loan officer and a decentralized loan decision at the branch office level through a credit committee.

Table 1 provides a characterization of non-agricultural and agricultural clients of $\mathrm{ABT}$ and $\mathrm{ABM}$ and even further classification of both animal and fruit and vegetable producers. Whether a client is classified as an agricultural entrepreneur is decided by the banks along the following two criteria: First, more than $50 \%$ of the client's household income needs to be generated through agricultural production, i.e. crop, fruit and vegetable, or livestock production. Second, the client must use the loan for agricultural production purposes. This strict classification only covers primary agricultural producers. Clients with businesses only related to agricultural production (input supply for farmers, processing of agricultural produce) are not considered as agricultural clients. Based on the seasonality of a farmer's production type, he can be granted a standard loan or a flex loan.For Tanzania, table 1 reveals that farmers are mostly animal producers, are on average five years older, have a slightly larger family size, are mostly female, and are better educated than non-agricultural loan applicants. In Madagascar, household income and household expenses of farmers are lower than for non-farmers. There is a lower share of female clients in the group of farmers with flex loans compared to farmers with standard loans and non-farmers. Furthermore, farmers with flex loans are mostly crop and vegetable producers, and farmers with standard loans are mostly animal producers.

\section{Evaluation Questions and Methodology}

Taking into account the attributes of standard loans and flex loans and the existing experience with the effects of inflexible repayment schedules on credit access for firms with cyclical cash flows, we will assess the overall success of the introduction of flex loans along the following evaluation questions:

1. "Product": $\quad$ Are lending principles and product characteristics of flex loans adapted to farmers' needs?

2. "Credit Access": How far can standard loans and flex loans achieve the financial inclusion of farmers?

3. "Loan Repayment": Does the financial inclusion of farmers increase the credit risk of the MFIs?

4. "Sustainability": Is agricultural lending a strategic field of business for ABM?

In order to answer our evaluation questions, we chose a mixed-method approach, consisting of (I) the investigation of the flex loan procedures in AccèsBanque 
Madagascar, based on field visits to two branch offices in different regions of Madagascar and semi-structured interviews with the bank's staff and clients; and (II) an in-depth portfolio analysis of ABT and ABM.

For (II) we applied data-adjusted regression analyses to investigate (a) the probability that a loan applicant receives a loan when he applies for one, (b) when an applicant is granted a loan, how much of the amount he is asking for finally is approved (this approach corrects also for likely income differences), and (c) how many of the loan installments the borrower has to pay are not paid in time. In all of our analyses, clients with standard loans (without grace periods) serve as the reference group. This reference group is plausible for three reasons: First, it comprises the majority of all borrowers; second, this group can be observed since the MFIs were founded; and, third, this group is the benchmark for both banks' management to judge the success of any product modification.

The datasets we use for the portfolio analyses comprise all microloans both banks have disbursed since the first month of operation (ABT: November 2007, ABM: February 2007) until April 2011 (ABT) and May 2012 (ABM). Our data was extracted from the Management Information System (MIS) of the banks and include loan and respective client data. The loan data (e.g. number of installments, interest rate) are generated automatically by the MIS as soon as a loan is disbursed. The client data which is generated through the in-depth client assessments by the loan officers is entered manually into the MIS. Consequently, it was necessary to clean the client data for obvious data entering errors and outliers, which was jointly conducted with the staff of both banks. Furthermore, we excluded those loan applications that were withdrawn by the client before the bank had made a loan decision, loans that were still in the decision process, and loans with incomplete client or loan data.

The in-depth portfolio analyses summarize the key results of Weber and Musshoff (2012), Weber and Musshoff (2013), and Weber et al. (2013). The reader is referred to these articles for a detailed explanation of applied regression approaches and the regressions results.

\section{$5 \quad$ Evaluation Results}

\subsection{Are Lending Principles and Product Characteristics of Flex Loans Adapted to Farmers' Needs?}

This section is based on field visits to different branch offices of ABM in April 2013 and semi-structured interviews with the banks' staff and clients.

In Madagascar, about $70 \%$ of the total population (most of it living in rural areas) is employed in the agricultural sector, and the mainly small scale agricultural sector contributes about $30 \%$ to the country's GDP, after the (mainly informal) services and (mining) industries sectors. Hence, for ABM to successfully reach 
small entrepreneurs in rural areas it has to ultimately acknowledge agricultural production circumstances and simultaneously consider the local specifics in the microfinance sector. For this reason, ABM introduced flex loans four years after its foundation but only in selected branch offices in rural areas.

The difference between standard loans and flex loans is the consideration of future cash flows of the client to determine the client's repayment capacity, i.e., the amount the client is able to use for loan repayment per month as loans of ABM must be repaid on a monthly basis. For standard loans, typically the cash flows of the client during a given period before the loan application are expected to also occur in the future. The repayment capacity is calculated on the average monthly cash flow minus all the client's private expenditures reduced by $30 \%$ to allow covering unforeseeable expenses (e.g., accidents). For flex loans, the transfer of past cash flows would be misleading as most farmers (despite the high seasonality of expenditures and returns) usually rotate crops year by year. Furthermore, commodity prices vary. Thus, the responsible loan officer has to structure a cash flow calendar by evaluating not only plantation and harvesting periods but also all related costs and returns of an agricultural activity on a monthly basis. Because most farmers' agricultural activities are diversified, this needs to be done for all agricultural activities of the farmer. As most farmers also have income from non-agricultural sources, these sources also need to be considered and might even have to be assessed with the procedures for standard loans. The higher the farmer is diversified, the less likely it is that he will c.p. face months with negative cash flows and, hence, negative repayment capacities. Nevertheless, flex loans allow for granting grace periods for months with negative cash flows. ABM grace periods are defined by months with loan repayments below the annuity that would be due with the application of a standard loan. There are also consecutive grace periods possible, and cash-flow analyses are verified by credit committee members for each loan on the branch level. One further difference to standard loans is the frequency and the purpose of visits to clients after loan disbursement. While with standard loans only one visit is foreseen to keep in contact with the client before the first repayment installment (for standard loans typically one month after disbursement), one additional visit takes place with flex loans. The purpose of visits is to verify that the loan was used to finance the intended activity. The reason for this verification is that for the cash-flow estimation the returns of the financed activity were considered, and a deviation (e.g., when the farmer plants another crop) increases the probability that the client runs into repayment problems.

Concluding, these flex loan procedures show that lending principles in ABM are designed to respond to the farmers' needs. They further demonstrate that loan officers in agricultural lending need special skills. They must be experienced with standard loan procedures and need to have a profound understanding of farming. 


\subsection{How Far Can Standard Loans and Flex Loans Achieve the Financial Inclusion of Farmers?}

This section is based on mean comparison tests between agricultural and nonagricultural clients of $\mathrm{ABT}$ and $\mathrm{ABM}$ as well as regression analyses wherein the sector affiliation of the client was considered as an additional control variable.

Our results for Tanzania reveal that farmers applying for standard loans have a lower probability of receiving a loan than non-agricultural firms. Furthermore, the loan amounts for farmers with access to credit are not significantly different than those for other clients of ABT. Our results for Madagascar, however, are different. Here, farmers applying for standard loans have the same probability of receiving a loan as non-farmers. The results further show that farmers applying for flex loans have a higher probability of receiving a loan compared to non-farmers. For the loan amounts disbursed, we find that farmers with standard loans receive larger loan amounts than non-farmers. For farmers with flex loans, we find lower disbursed loan amounts compared to non-farmers. When comparing farmers with standard and flex loans, we find that farmers with flex loans have a higher probability of receiving a loan than farmers with standard loans. In contrast, we find a largely negative effect for the disbursed loan amounts, indicating that farmers with flex loans receive smaller loans than farmers with standard loans, a result which might be related to the cautious lending practice, i.e., the perceived credit risk of ABM for clients with flex loans. Of further importance for the interpretation of these results is the consideration of the loan distribution among agricultural production types financed through both loan products. Here our data reveal that almost all flex loans were granted to crop and vegetable producers whereas standard loans were mostly granted to animal producers.

We conclude that the better credit access probabilities for seasonal farmers indicate that providing flex loans helps to financially include farmers with seasonal production types. The loan distribution amongst production types for both banks further reveals that the client share of seasonal agricultural producers was rather low when flex loans were not accessible. This suggests that without providing flex loans, non-seasonal agricultural producers would be addressed by the banks, but it is unlikely that seasonal agricultural producers would be given credit access at all.

\subsection{Does the Financial Inclusion of Farmers Increase the Credit Risk for the MFIs?}

This section is solely based on regression analyses wherein the sector affiliation of the client was considered as an additional control variable.

Our findings for $\mathrm{ABT}$ indicate that agricultural clients with standard loans report lower delinquencies than non-agricultural clients. For ABM, our results reveal no significant delinquency differences between farmers and non-farmers with standard loans (both without grace periods). Taking into consideration that most farmers with standard loans are animal producers with continuous returns, this re- 
sult does not seem surprising. In contrast, we find higher delinquencies for farmers of ABM with flex loans than for non-farmers with standard loans (both without grace periods). This suggests that while the provisioning of flex loans seems to be a prerequisite to creating credit access for farmers with seasonal production types, flex loans without grace periods cannot overcome seasonality related repayment risks of seasonal agricultural producers. However, this difference disappears for those farmers with flex loans that were granted a grace period. Hence, grace periods are crucial for flex loans to bridge the wedge between discontinuous returns and continuous repayment obligations.

To sum up, from a risk perspective our findings reveal that standard loans seem to be adequate for farmers with continuous returns and that grace periods are crucial for financially including farmers with seasonal production types without increasing delinquency levels. Moreover, our results confront the widespread wisdom that agricultural borrowers are generally riskier than non-agricultural borrowers when they are adequately addressed.

\subsection{Is Agricultural Lending a Strategic Field of Business for ABM?}

This section is based on field visits to different branch offices of ABM in April 2013 and on semi-structured interviews with the banks' staff and clients.

After two years of lending experience with flex loans and, hence, the agricultural sector, ABM began to further develop the agricultural lending business with products corresponding to the clients' needs (warehouse receipt loans, value chain loans). This seems especially plausible as the agricultural sector contributes about $30 \%$ to the country's GDP. Considering at the same time the high share of people employed in agriculture, the challenge of agricultural finance in Madagascar is the fragmentation of the sector, resulting in high costs per disbursed loan. These higher costs have to be compensated by the interest rates charged. Thus, even if the efficiency of loan provisioning by ABM can be considered as high, agricultural lending is associated with higher lending costs when farm sizes remain small. The question is whether and how ABM can overcome this problem. Seeking for a further standardization of the flex loan lending principles seems to be a promising field of intervention. Yet, given the already high efficiency of ABM in agricultural lending, the cost reduction potential here is limited. The increase of the average farm size resulting in larger requested loan sizes could circumvent this dilemma; however, this is beyond the banks' influence (unless the bank would strategically focus on larger farmers, which is not the case) and will depend on the general economic development of Madagascar. If employment opportunities emerge, people will migrate to urban areas and, hence, sell or lease their property to others. During the field visits such tendencies could be observed although these observations cannot be generalized for the agricultural sector as a whole. However, looking at the profit margins of ABM's agricultural producers (both seasonal and nonseasonal), there is no reason to assume that farmers are unable to cover the (only 
slightly) higher interest rates charged by ABM for flex loans. Taking this into consideration we would like to state explicitly that we find no reason for political interventions in agricultural lending (e.g., interest subsidies, interest rate caps) in Madagascar. Given the sustainability of agricultural lending in ABM and the short time period of only two and a half years the bank has experience with flex loans, we even believe that any market distorting lending policy intervention would jeopardize the strategic focus of ABM towards agricultural lending. At the moment, however, there is no such intervention in sight. Furthermore, not only the costs of borrowing determine the decision whether and from which institution farmers borrow. We find that when farmers request loans, the money is needed at that time (and not a month later). The fast loan processing time (1-7 days from application to disbursement) can be considered as the most important competitive advantage for ABM generally and for the agricultural lending business in particular.

The sustainability of ABM's agricultural lending will also depend on how the bank will be able to manage the weather risk exposition and specifically covariate weather risks in its loan portfolio in the future. Here, the geological conditions of Madagascar which split the island into different ecological zones sensitive to different weather events guarantee a natural diversification to some extent. The same follows (with regional differences) from farmers' generally well diversified production schemes. However, extreme weather events (e.g., droughts in the western part or hurricanes in the eastern part of the island) can instantaneously affect all seasonal production types in one region. In order to avoid largely negative effects on the banks' performance, ABM can either continue to conservatively assess agricultural yields and commodity price developments or seek for risk transfer instruments (or both). The latter might be too early to consider as the bank currently has only $3.8 \%$ of the total loan portfolio exposed in the primary agricultural sector. However, the bank seeks for an (primary) agricultural share of the total loan portfolio of up to $25 \%$ which might be a different story.

In conclusion, we consider agricultural lending a strategic field of business of ABM. The positive experiences with flex loans have even led to further focusing the agricultural sector in Madagascar by the introduction of new products. Additionally, the positive experience of ABM has led to the launch of flex loans by ABT (and further banks of the AccessHolding Microfinance AG in Africa will follow). Moreover, the warehouse receipt loans which were only recently introduced by ABM already showed demonstration effects for one other MFI in Madagascar.

\section{References}

Adams, D.W., Graham, D.H. (1981) A critique of traditional agricultural credit projects and policies. Journal of Development Economics 8(3):347-366.

Armendáriz de Aghion, B., Morduch, J. (2000) Microfinance beyond group lending. Economics of Transition 8(2):401-420. 
Armendáriz de Aghion, B., Morduch, J. (2010) The economics of microfinance, 2nd ed. Cambridge, London: The MIT Press.

Binswanger, H.P., Rosenzweig, M.R. (1986) Behavioural and material determinants of production relations in agriculture. Journal of Development Studies 22(3):503-539.

Caudill, S.B., Gropper, D.M., Hartaska, V. (2009) Which microfinance institutions are becoming more cost effective with time? Evidence from a mixture model. Journal of Money, Credit and Banking 41(4):651-672.

Christen, R.P., Pearce, D. (2005) Managing risks and designing products for agricultural microfinance: Features of an emerging model. CGAP Occasional Paper, No. 11.

Czura, K., Karlan, D., Mullainathan, S. (2011) Does flexibility in microfinance pay off? Evidence from a randomized evaluation in rural India. Paper presented at the Northeast Universities Development Consortium Conference 2011, Yale University.

Dalla Pellegrina, L. (2011) Microfinance and investment: A comparison with bank and informal lending. World Development 39(6):882-897.

Duvendack, M., Palmer-Jones, R., Copestake, J.G., Hooper, L., Looke, Y., Rao, N. (2011) What is the evidence of the impact of microfinance on the wellbeing of poor people? EPPI-Centre, Social Science Research Unit, Institute of Education, University of London, London.

Field, E., Pande, R. (2008) Repayment frequency and default in microfinance: Evidence from India. Journal of the European Economic Association 6(2-3): 501-509.

Field, E., Pande, R., Papp, J., Rigol, N. (2011) Debt structure, entrepreneurship and risk: Evidence from microfinance. Harvard Working Paper.

Godquin, M. (2004) Microfinance repayment performance in Bangladesh: How to improve the allocation of loans by MFIs. World Development 32(11):19091926.

Hermes, N., Lensink, R., Meesters, A. (2011) Outreach and efficiency of microfinance institutions. World Development 39(6):938-948.

Jain, S., Mansuri, G. (2003) A little at a time: the use of regularly scheduled repayments in microfinance programs. Journal of Development Economics 72(1): 253-279.

Kong, R., Turvey, C.G. (2008) Vulnerability, trust and microcredit: The case of China's rural poor. Research paper / UNU-WIDER, Vol (2008)52, UNUWIDER, Helsinki.

Krahnen, J.P., Schmidt, R.H. (1994) Development finance as institution building. A new approach to poverty-oriented banking. Boulder: Westview Press Boulder. 
Llanto, G.M. (2007), “Overcoming obstacles to agricultural microfinance: looking at broader issues", Asian Journal of Agriculture and Development 4(2):23-39.

Love, I., Peria, M.S.M. (2012) How bank competition affects firms' access to finance. The World Bank, Development Research Group, Policy Research Paper No (6163).

Maurer, K. (2011) Mobilising Capital for the Poor - How Does Structured Finance Fit in Emerging Markets?” In: Köhn, D. (ed.), Mobilising Capital for Emerging Markets. Berlin Heidelberg: Springer, pp. 13-27.

Meyer, R.L. (2002) The demand for flexible microfinance products: Lessons from Bangladesh. Journal of International Development 14(3):351-368.

Pande, R., Cole, S., Sivasankaran, A., Bastian, G.G., Durlacher, K. (2012) Does poor peoples' access to formal banking services raise their incomes? A systematic review. EPPI-Centre, Social Science Research Unit, Institute of Education, University of London, London.

Shankar, S. (2007) Transaction costs in group microcredit in India. Management Decision 45(8):1331-1342.

Taylor, M. (2011) Freedom from poverty is not for free: Rural development and the microfinance crisis in Andhra Pradesh, India. Journal of Agrarian Change. 11(4):484-504.

Vogelgesang, U. (2003) Microfinance in times of crisis: The effects of competition, rising indebtedness, and economic crisis on repayment behavior. World Development 31(12):2085-2114.

Weber, R., Musshoff, O. (2012) Is agricultural microcredit really more risky? Evidence from Tanzania. Agricultural Finance Review 72(3):416-435.

Weber, R., Musshoff, O. (2013) Can flexible microfinance loans improve credit access for farmers? Agricultural Finance Review 73 (in print).

Weber, R., Musshoff, O., Petrick, M. (2013) How flexible repayment schedules affect credit risk in microfinance. Paper presented at the International Agricultural Risk, Finance and Insurance Conference (IARFIC), Vancouver, Canada, June 16-18, 2013.

Open Access. This chapter is distributed under the terms of the Creative Commons Attribution Noncommercial License, which permits any noncommercial use, distribution, and reproduction in any medium, provided the original author(s) and source are credited. 